\title{
Gender perspectives in mathematics education: intentions of research in Denmark and Norway
}

Tine Wedege, The School of Teacher Education, Malmö University, Malmö, Sweden, and The Department of Mathematical Sciences, Norwegian University of Technology and Science, Trondheim, Norway

\begin{abstract}
A framework is presented for analyzing gender perspectives in mathematics education (structural, symbolic, personal and interactional gender), and the Danish and Norwegian researchers'/ teachers' work within the field of gender and mathematics is presented with reference to these four perspectives. Furthermore, the gender issue in TIMSS and PISA is briefly discussed. The main thread through the article is the researchers' willingness and intentions of investigating the gender perspectives in mathematics education. However, so far, these research intentions have not been realized in Denmark and Norway.
\end{abstract}

\section{Gender as a dimension or a background variable}

Gender mainstreaming is a principle that means bringing gender thinking into the main stream - into all decision making and organizational (...) work. Many have used the image of gender equality as something that flows in its own tributary. Through gender mainstreaming, equal opportunities are brought into the main stream - i.e. the ordinary organizational and political efforts.

(Danish Trade Union Movement, 2003)

Since the beginning of 1990s, the international debate on gender in mathematics education has been reflected in a series of conferences held in Denmark and Norway, and the teachers/researchers have also participated in the Swedish "Mathematics and women" conferences. However, there are very few studies in Denmark and Norway designed with the main purpose of investigating gender and mathematics.

The researcher chooses to focus on certain factors and dimensions in order to undertake his or her investigation, and gender is one of the variables or dimensions to decide upon. If you agree with the view of mathematics education research as "the collective effort to study and to shape the relationship between humans, on the one hand, and mathematics, on the other." (Fischer, 1993 p. 113) and if you realise that this relationship has a societal dimension as well as a cognitive and an affective dimension, then you must acknowledge gender as a key dimension. However, in every scientific study on mathematics education it is necessary to reduce the complexity of the problem field. Two principles might be used for removing the gender perspective: Would it be appropriate as regards validity and reliability of the study? Is it appropriate to investigate this particular problem without involving a gender perspective? Is gender a relevant or even necessary variable/dimension in the study? Would it be legitimate to (dis)regard the gender issue - taking into account that the principle of gender mainstreaming (i.e.: the recognition of what we have so far considered to be the standard - or the usual approach is not necessarily gender neutral)? In both cases one should examine whether the gender dimension might influence the situation to be investigated. Thus, the two principles lead to the same choice concerning the gender perspective in a study on mathematics education: whether to involve gender as a dimension or a variable or not.

The theme of this article is "Research on gendered mathematics - a Danish/Norwegian perspective." Whether the issue is gender difference or gender equity, in the Nordic countries the 
underlying issue will always be equal opportunity. Since 1991 a series of conferences has been held in the two countries with focus on gender, and teachers/researchers have also participated in the Swedish "Mathematics and women" conferences since 1990. However, there are very few Danish and Norwegian studies which deal with mathematics education designed with the main purpose of investigating gender and mathematics. The other papers in the Nordic gender conference proceedings adressed women in mathematics research, mathematics educational systems in Denmark and Norway, or results from mathematics education research where gender - mostly as a background variable - was brought into focus for these special occasions. In none of the 11 volumes of the journal "Nordic Studies in Mathematics Education" (1993-2006), may you find a Danish or Norwegian article with focus on gender. However, among people in the field of doing research, I have detected intentions to have gender as a main focus.

In this article, I present four perspectives for analyzing gender in mathematics education (structural, symbolic, personal and interactional gender). Within a model inspired by Kaiser and Rogers, I discuss the Danish and Norwegian papers presented at the Nordic gender/women and mathematics conferences with reference to these four perspectives. Furthermore, I briefly present and discuss some of the findings on gender in TIMSS and PISA. Finally, I conclude with a question on future directions.

But first, I have a short comment on terminology. In the 1990s, a transition took place in the debate on women and mathematics: from using the word "sex" with focus on biological aspects, the debate turned to "gender" with a focus on the sociological aspects (see e.g., Burton, 1990; Grevholm \& Hanna 1995; Kaiser \& Rogers, 1995; Hanna, 1996; Leder, Forgasz \& Solar, 1996). Today in the Swedish discourse on gender and education, a clear distinction is made between the two terms sex (kön), which refers to female and male, biological differences, chromosomes, hormonal profiles, versus gender (genus), which refers to feminine and masculine, characteristic and culture dependent traits attributed by society to men and women. In Denmark and Norway we do not mark this difference explicitly in educational discourse. The Danish word is "køn" and the Norwegian "kjønn". In this article, the English word gender is used with the meaning of "genus", unless the Norwegian or Danish word is applied or the meaning of the word in the paper referenced is in fact “sex".

\section{Doing gender in mathematics education}

According to Kaiser (2003) the social construction of gender forms the theoretical base of many new empirical studies dealing with the topic Mathematics and Gender. In the pioneering article “Doing gender", West and Zimmerman (1987) presented an understanding of the interactional work involved in being a gendered person in society. In this context, doing gender means "creating differences between girls and boys and women and men, differences that are not natural, essential or biological” (p. 136). When the differences have been constructed, they are used to reinforce the nature of gender. According to West and Zimmerman, a person's gender is not simply an aspect of what one is, but more fundamentally it is something that one does recurrently in interaction with others. In this article, I refer to four aspects of "doing gender" which are presented and used by Harriet Bjerrum Nielsen (2003) in a European study of gender in scouting. In this framework, "doing gender" also includes action and interaction and furthermore being gendered and interpreting gender. 
Together with the Norwegian Moncia Rudbjerg, Bjerrum Nielsen ${ }^{1}$ has distinguished two aspects of psychological gender: gendered identity (I am a woman/man hence I act like I do) versus gendered subjectivity (I am me hence I act like I do $)^{2}$. The gendered identity is something you have while the gendered subjectivity is something you are. It was their hypotheses that gendered identity is a changing phenomenon while gendered subjectivity shows much more continuity, both historically and in the life of the individual (Bjerrum Nielsen \& Rudberg, 1994). Girls choosing to be a nurse might do it both because it confirms their gendered identity (it is feminine to help others), and because their gendered subjectivity has the effect that they feel in fact that it is meaningful and confirmatory to them as persons to help others. While boys choosing to study mathematics might do it because it confirms their gendered identity (it is masculine to do mathematics), and because their gendered subjectivity has the effect that they feel in fact that it is meaningful and confirmatory to them as persons to be occupied with mathematics.

The question "What is gender?" might at first look as an easy one to answer. Of course "gender" means men and women, boys and girls, and all the differences between them. However, the question is much more complex as the examples of gendered choices of career have shown. We not only assign gender to people with a different sex but also to colours, jobs, school subjects, clothes and leisure activities. In order to study different dimensions of the gender issue, Bjerrum Nielsen includes four perspectives: structural, symbolic, personal and interactional gender.

For a first illustration of these perspectives, I have translated an episode with a pink eraser in the mathematics classroom from a similar episode with a pink soapbox observed in the European project on "gender in Scouting” (Bjerrum Nielsen, 2003 p. 10):

The mathematics teacher asks Niels to rub out a diagram in his exercise book. Niels inquires if any one has an eraser. Anne fetches her eraser, gives it to him, and he teases her because it is pink.

Anne was teased in the mathematics classroom because of her pink eraser. Would this have happened if the eraser was blue or yellow? Gender exists in the world and in people's head as mental models, and what we perceive as gender is always a product of an ongoing interaction between "gender in the head" and "gender in the world". The episode with the pink eraser illustrates how girls are doing services to boys in the mathematics classroom (structural gender); that femininity is not highly valued in this context (symbolic gender); that Anne seams eager to serve the boys, while Niels seams eager to push femininity away (personal gender); and finally how Niels positions Anne, and she gets feedback on limits of "doing femininity" in the mathematics class room (interactional gender).

The first perspective is structural gender: gender constitutes a social structure where for example men and women are unevenly distributed in terms of education and occupations; men earn more than women, who also hold fewer leading positions in society; women do more housework in most families. Another example of structural gender is the clear division of gender in the Danish technical schools of the 1990s (Hansen, 1991, 2000). The higher secondary level with technical mathematics and physics (called "TX") and the vocations in metal and building industries were mainly chosen by boys while vocations like hairdresser and "sandwich maker" were primarily chosen by girls.

\footnotetext{
${ }^{1}$ Harriet Bjerrum Nielsen is a professor at the Centre for Women's Studies and Gender Research at the University of Oslo. In the early 1980s, she did her Ph.D. in Denmark where she was one of the very first to study classroom activities from a gender perspective.

${ }^{2}$ Originally, the aspects were named "gender identity" and "gendered subjectivity", but later Nielsen has changed the term into gendered identity to make visible the possible change.
} 
The second perspective is symbolic gender: the gendered structures gradually form the gender symbols and discourses (symbolic meaning) in people's heads. It becomes, for example, normal and natural that men take the leading positions in society while women have part time jobs to take care of home and family. "Thus, symbolic gender will have consequences for the further development of structural gender, and vice versa” (Bjerrum Nielsen, 2003, p. 18). Doing gender is also interpreting gender.

Quantitative methods have been used internationally to investigate structural and symbolic perspectives on gender in mathematics education, mainly in terms of gender differences. From the mid 1970s, Fennema and Sherman's Mathematics Attitudes Scales (MAS) were used to measure gender differences in, for example, self-confidence, mathematics anxiety and ideas of mathematics. In the late 1990s Forgasz and Leder (1999) re-examined the scales and showed that several items of the "Mathematics as a Male Domain" scale were no longer valid. When the scale was developed there was no reason to believe that mathematics could be considered as a female domain, and a negative response to the items was interpreted as an attitude to mathematics as a neutral domain. Forgasz and Leder suggested that low scores on this scale could no longer be interpreted as a reflection of stereotyping of mathematics as a male domain. Accordingly, the scale was revised into a "Who and Mathematics" scale and it was tested in a Swedish study, where the revision showed up to be a relevant (Leder and Brandell, 2004; see also Brandell, Leder, and Nyström in this issue).

Structural and symbolic gender tells us what is normal and what is deviant for men and women, girls and boys whether we personally consent to these norms or not. Gender becomes a framework of interpretation. In the Danish technical schools in the beginning of the $1990 \mathrm{~s}^{3}$, Mathematics has its own place in the symbolic gender dualism of the society, where the world and its qualities are divided into masculine and feminine, and where everybody has integrated this dualism whether they want to do it or not. Mathematics is a masculine area of competence with its logic and precision and this symbolism becomes generally accepted by the students. This goes for optional (more advanced) and compulsory (basic) mathematics and technical mathematics in the TX-classes. The boys at optional mathematics classrooms do not speak about mathematics being difficult; they speak about the bad teachers and say that they do not feel like working with it, that they would rather use their body (Hansen, 1991, p. 51).

One of the consequences of this dualism is that teachers - despite their good intentions - might use different standards for boys and girls:

In one of the classes (...) one of the girls had grade 6 and one of the boys had grade 00 [respectively, a grade below medium and the lowest grade possible]. The teacher said that he was not the bit worried for the boy because he was very likely to learn it. On the other hand he was worried about the girl because she was working hard. In fact, the boy did so too but it is in the air that it is the boys' nature to learn mathematics, while the girls have to fight against their natural disposition (Hansen, 1991, p. 52).

Unlike in the TX-classes, mathematics symbolises something other than being clever in the vocational training classes. Here it was associated with school, being quiet, doing your homework,

\footnotetext{
${ }^{3}$ A study on "gendered mathematics" was designed and carried through by the Danish psychologist Kirsten Grønbæk Hansen in the early 1990s (the empirical investigation) and later. She studied the activity in the mathematical classrooms in technical schools (vocational education and TX - technical higher secondary school). The main purpose of the study was to investigate the personal meaning of mathematics to the students and how this was connected with the cultural meaning of mathematics. The examples given in this section to illustrate the theoretical framework are findings from her work (Hansen, 1991, 2000).
} 
and the girls are the best in mathematics, which is OK. In this context, it is not cool for the boys to be clever in mathematics (Hansen, 2000).

A third perspective is personal gender where gender is seen as a personal matter and a reality for everybody. People are not passive bricks in social and cultural structures. They shape their lives within these structures, discourses and norms, and gender in the world is more diverse than the often dichotomous and stereotyping gender in our heads. "Personal gender concerns the way we fit into (or do not fit well into), identify with or protest against available cultural models of gender" (Bjerrum Nielsen, 2003, p. 22).

In the early 1990s, most of the students in Danish technical schools came from homes unfamiliar with education. The girls in the TX-classes were in a process of upward social mobility and they used the masculine field. By doing mathematics they could destinguish themselves from the other girls. The boys were vulnerable in their social climbing. They had to leave their old background for gendered identity (muscle power and technical ingenuity). Their gendered subjectivity was threatened because the hierarchy made it difficult for the boys to move into the fields of the girls (Hansen, 1991).

A fourth perspective is interactional gender where gender is seen as something created and reproduced continuously through social interaction (negotiation). This perspective emphasises gender as something we "do" whether the body and subjectivity perspective emphasises gender as something we "are". When people interact they continuously negotiate who they are and who others are. They position themselves and others as gendered, and they get feedback on these positions.

In TX-classrooms, the girls do not have the same legitimate access to high status in the mathematics classroom as the boys. Although a girl, Karina, is the best in mathematics in one of the classes, she does not get this status. The students go against their direct classroom experiences and define the clever girl as out of this position. Also the teachers find it difficult to recognize the girls' competences even when they are obvious. Good performance of a girl is often followed by a doubtful shake of the head: she was certainly very hard-working (Hansen, 2000).

These four perspectives on gender do not refer to different acts or situations. They are different analytical perspectives to be applied to the same activity or situation. In the next section, I shall make reference to these perspectives in the presentation of papers and work done within the field of gender and mathematics in Denmark and Norway.

\section{Gender and mathematics}

Among the Nordic countries, Sweden is the "big sister" within the field of gender and mathematics. The first national conference, within the framework of The International Organization of Women and Mathematics Education (IOWME), was organised by Barbro Grevholm in Malmö, in 1990. The title of this conference as well as the following five conferences held in Sweden was "Women and mathematics" (Swe: Kvinnor och matematik). On the list of 130 participants, you may find two Norwegians and three Danes (see Grevholm, 1992). A national Swedish network was established at this conference as a sub-organisation of IOWME and it attracted more than 700 members in 1996. In mathematics education, we do not have anything like that in Denmark and Norway.

The first and only Danish conference under the auspices of IOWME was held in Copenhagen, 1991, with 80 participants (Tingsleff, 1991). In Norway, 1992, the first conference on women and mathematics was held in Kristiansand in cooperation with the Norwegian Mathematics Council, represented by Kari Hag and 100 participants (Sekretariat for kvinneforskning, 1993). The second 
conference - this time with a focus on girls and mathematics in an action and a classroom perspective - was organised in Trondheim, 1999 (Hag, Holden \& Marion, 2000). The last Norwegian conference "Women in science (including mathematics)" was held in Bergen, 2003 (Skarsbø, 2004). Only a few papers presented by Danes or Norwegians from the field of mathematics education at these conferences were based on research with a gender perspective. However, some of the central international researchers within the field were invited as plenary speakers; e.g. Leone Burton (1992), Gila Hanna (1993), Gilah Leder (2000) and Valerie Walkerdine (1991).

An international colloquium on "Differential performance in assessment in mathematics at the end of compulsory schooling” was held at University of Birmingham, 1992. Denmark was represented by Haastrup and Lindenskov (1994) and Norway by Berge and Haga (1994). They presented mathematics in their educational systems with comments on gender issues, as did Branner, Faistrup and Kock (1996) and Hag (1996) at the 1993 ICMI study conference "Gender and mathematics" in Höor, Sweden. With this initiative, the International Commission on Mathematical Instruction (ICMI) wanted to address gender inequity as a key issue in mathematics education (Grevholm \& Hanna, 1995). Since the $6^{\text {th }}$ International Congress on Mathematics Education (ICME 6) in Budapest 1988, IOWME has been an officially accepted study group and the organization has therefore run extensive sessions at each congress. Following the work of IOWME the first working group on Gender and Mathematics listed in the official conference program was organised at ICME 8 in Seville 1996. Here, Norwegian Kari Hag presented the ideas from a round table on Women and Mathematics at the Second European mathematics conference in 1996 (see Grevholm \& Evans, 1998). At ICME 10, in Copenhagen, 2004, Norwegian Liv Sissel Grønmo was a team chair of the topic study group Gender and Mathematics Education but there were no paper presentations from Norway or Denmark (see www.ICME10.dk).

\subsection{Lessons on the gender perspective}

In the book “Equity in mathematics education”, Kaiser and Rogers (1995) - applying McIntosh’s model of stages of awareness to mathematics - discern five phases of reform in mathematics education: (1) Womanless mathematics; (2) Women in mathematics; (3) Women as a problem in mathematics; (4) Women as central to mathematics; and (5) Mathematics reconstructed. (See also a presentation of the stages in Leder, Forgasz \& Solar, 1996.) Kaiser and Rogers point out that these phases of reform in mathematics do not always occur in chronological order and that all western countries are not simultaneously at the same stage. It is not possible to locate stages like these in the Danish and Norwegian work with a gender perspective on mathematics education presented at conferences, in the period from 1990 up untill now. However, I find it meaningful to look at these papers through the lenses of the five phases model:

The title of the first women and mathematics conference in Norway was "Research in mathematics education and women in mathematics", and the Norwegian male researcher in mathematics education, Gard Brekke, and the Danish male researcher, Mogens Niss, lectured at this conference. But none of them referred to the gender perspective. In this context, you might say that they presented a genderless mathematics: not even the students in their lectures were gendered in that they were named "boys" and "girls" (Sekretariatet for kvinneforskning, 1993). Women in mathematics characterizes the work where prominent female mathematicians were made visible in paper presentations at the conferences (Andersen, 1991; Hag, 1998; Piene, 1994). In Denmark, Else Høyrup (1978) had written an annotated bibliography on women and mathematics, science and engineering, and much later Tinne Hoff Kjeldsen (2001) edited a special issue on women and mathematics in the Newsletter of the Danish Mathematical Society. These publications contribute to 
knowledge on the structural gender perspective but also on the symbolic gender perspective. Norwegian Stieg Mellin-Olsen (1995) made a contribution to the latter in a posthumously published book of interviews that he had made with nine prominent female mathematics educators. He made the following comment on the results: "I am convinced that any sample of male colleagues could not produce texts with similar qualities as did these women.”

Women as a problem in mathematics education was a central theme at the ICMI study conference in terms of inequity and this issue was an explicit topic in the Nordic or other national conferences by the question: "Women in mathematics: why so few?" (Hag, 2000). In the international comparative surveys like TIMSS and PISA, the gender issue has been treated in terms of differences from a structural perspective (performance of girls/women versus boys/men) and from a symbolic perspective (girls'/women's versus boys'/men's attitudes towards mathematics). This was also the case in the quantitative, Norwegian study (Skaalvik, 1990). In contrast to TIMSS and PISA, no gender differences were found in achievement (however overestimated by the boys) or in mathematics self-efficacy. A contrary finding might also have been given by Norwegian Gustafsson (1993) in her presentation "Gifted girls and their school performance in mathematics” but her conclusion was that the girls did not perform according to their intellectual potential in the school and especially not in mathematics.

In the Norwegian project KIM (Quality In Mathematics education), differences between boys' and girls' attitudes towards mathematics were investigated in a survey. At the gender and mathematics conference in Trondheim, Brekke and Streitlien (2000):

It is complicated to measure the affective dimension of a school subject. (...) Hence, we wish to make a follow up to this investigation using qualitative methods as for example classroom studies and interviews with selected groups of informants (p. 47).

Gender as a central perspective in mathematics education is illustrated by Grønbæk Hansen's findings, some of which are presented above (Hansen, 1991, 2000). Her research is the only qualitative study designed to investigate gender perspectives. However, the intention of making gender a central dimension is expressed by more researchers. Here Danish Lena Lindenskov comments

Throughout history, gender has been one of the most important parameters in societal divisions of work and distribution of power, and this is still the case at the entrée to the next millennium, even in the Nordic societies. Hence, it is obvious - in mathematics education research - to investigate systematic traits related to gender in mathematics teaching and mathematics learning.

(Lindenskov, 2000, p. 109)

Lindenskov was one of the organisers of the first and only Danish conference. In her plenary lecture entitled "A tribute to curiosity", she presented some preliminary results from her doctoral work stressing that the women perspective was not her interest in this study (Lindenskov, 1991). In her workshop, entitled "Fascination, self-presentation and gender in school mathematics", at the second gender conference in Norway, she presents observations from her qualitative study on what she called "students' personal curriculum" in the early 1990s. The title may suggest that the perspective is personal gender. However the study had not been designed with the purpose of investigating gender, and the four students (two boys and two girls) represent four different curricula. It is the girl, Julie, who is fascinated by new applications, perspectives, and subjects of mathematics.

At the same conference, Maria Luiza Cestari (2000) presented the paper: "Boys and girls solving mathematical tasks: the co-production of gender dominance,” based on a Norwegian study. From the title one should think that the gender perspective was interactional. The dialogues observed and 
analysed are between two boys and two girls. As a reader you might extract the meaning of the title in Cestari's descriptions. The conclusion, however, does not include any statement on the gender issue.

At the fourth Swedish conference "Women and Mathematics" in Uppsala 1999, I was invited to give a lecture based on my doctoral study on adults and mathematics in the workplace. Although it would have been obvious, I had not taken an explicit gender perspective in this study. One of the reasons was that this new area of research was not cultivated and that the problem field was highly complex. Based on a mathematics life history interview with a 75 year old woman, I gave the lecture "Mathematics in a woman's school and everyday life" at the conference. In this study, I combined the theoretical frameworks of Lave (situated learning) and of Bourdieu (Habitus). Pieces of a puzzle with structural, symbolic, personal and interactional gender were ready to fall into place in the analysis providing an explanation for this mystery: the woman never realised her mathematical competence although she had the highest grade in mathematics in the technical school as a 50 years old, and she was highly competent in daily life situations with challenging mathematics (Wedege, 2001).

At a Nordic seminar "Gender, mathematics and technology", in Trondheim, 2005, (Wedege, 2006), Anne Berit Fuglestad gave the lecture "ICT tools in mathematics: boys' and girls' choice and attitudes” (Fuglestad, 2006). The findings were based on two studies (from 1995 and 2004) and they were produced for the special occasion of this seminar. The research questions in Fuglestad's mainly quantitative investigations did not involve any gender issues, but gender being a background variable in the study made it possible for her to answer the question "Is there any difference between boys' and girls' attitudes towards and thoughts about using computers in mathematics education?” During the session, Fuglestad distributed a couple of pages with students' responses to the questions "why did you like this problem?" - "what tool did you use and why?" - "what did you learn?”. The participants were invited to decide if the different answers were from boys or girls. In the debate, we were quite sure that for example the following reply came from a boy: "I liked this problem because it was solved really fast on the computer" (page 1), and that this came from a girl: "Computation of interest is fun and very useful. Our teacher has attached much importance to computation of interest and, hence, the problem is very easy to solve” (page 2). However, Fuglestad revealed that she had organised the students' replies with the girls on page 1 and the boys on page 2 . During this exercise symbolic gender was illustrated through our stereotyping of boys and girls, an issue which was precisely questioned at the seminar.

Fuglestad's study on technology from 2004 found only minor gender differences in attitudes. At two conferences in the late 1990s, Danish Mette Vedelsby presented her developmental work and related research on technology and gender. It was based on the question of whether it is possible to integrate IT in mathematics education in a way that makes it meaningful to boys and to girls. In her work, the premise was that boys are more attracted to technology than girls (Vedelsby, 1998, 2000). This is indeed a moving field and symbolic gender is changing, together with structural gender. At the seminar mentioned above, Rudolf Strässer (2006) ended his contribution as follows: “... I am NOT a specialist in the field of gender studies. I could and can only give my ideas and best knowledge in a field where much research is needed and where I am an amateur as are (unfortunately!) most of my colleagues” (p. 199).

Reconstructed mathematics charaterizes an idea of mathematics as including all people: instead of regarding the girls (or the boys) as the problem, you locate the problem in mathematics education and "mathematics will be what people do" (Kaiser \& Rogers, 1995 p. 9). Norwegian Ingvill Holden (now: Stedøy) presented the paper "Mathematics in primary: playing in the subject and subject in 
the play" at the conference in Trondheim, 1999. She reported from an action research project where the girls and boys after one year of learning mathematics in a context of play developed an open view of mathematics and a drive towards new and open problems, among other things (Holden, 2000). Stedøy, who is the leader of the Norwegian Center for Mathematics Education, is the driving force in the Nordic mathematics competition, KappAbel, where one of the basic principles is gender equity: the semi-final teams consist of two boys and two girls. This competition differs also in other aspects from mathematics competitions in general. The whole class co-operates as one participant and the classes have to do a project work with a specific theme. In 2004-2005, the theme was "Mathematics and the human body" and Wedege and Skott (2006) studied whether and how the KappAbel mathematics competition had any influence on the views of mathematics and the teaching/learning practices of the participating teachers and students. In this study, gender was a variable and it was found, from the survey, that non of gender, age, education nor school location for the teachers influenced the participation rate in the KappAbel contest in any significant way. Neither did gender influence the teachers' views on mathematics teaching and learning. In the interviews, most of the teachers took the general position that they did not think that gender mattered in the mathematics classroom. However, when it came to specific examples, one of the teachers talked about boys as being more confident and girls as having a deeper understanding in mathematics.

Another example of someone having an idea of reconstructed mathematics may be found in the work of Danish Inge Henningsen (2002). Taking a feminist position, she questioned the idea of gender neutral concept of numeracy, at a conference on adults learning mathematics in Roskilde, Denmark. She argued that men and women to a great extent inhabit different cultures both at work and in civic life. Thus, there is a need for a gender specific notion of numeracy and a gender conscious teaching of mathematics.

\section{Gender as a variable in TIMSS and PISA}

In the international comparative studies, gender - or sex - is a single variable among hundreds of other variables. But they might, in principle, throw some light on structural and symbolic gender in the participating countries. In TIMSS and PISA, boys generally score higher than girls in mathematics (with Iceland as an exception). This finding is however not consistent with the results in the national school tests, where, in general, no difference is found between girls and boys in mathematics. Recently the Danish Evaluation Institute published a report on boys' and girls' performances in education. They make this concluding comment: "This difference is certainly due to different methods for measuring the students' level of attainment” (EVA, 2005, p. 19). There is definitely a need to investigate what is measured in the surveys and why the methods give different results. The gender issue in TIMSS is in fact discussed by Norwegian Grønmo at three of the Nordic conferences (1995, 1998, 2000)

Denmark participated in TIMSS, 1991-1995, and in PISA in 2000-2004. The international comparison of 13 year-old students in 1995 showed that mean scores achieved by the Danish seventh grade students are approximately equal to the international results. But the comparison of the gender differences showed a different picture. Weng (1996) noted that the gender differences in mathematics performance were bigger than in most of the other countries in TIMSS. He concluded: “This is an interesting result, which requires an explanation” (p. 56). Eight years later, Lindenskov and Weng (2004) noted that the Danish results on gender differences in performance "unfortunately" are not surprising and they concluded that this was underexposed in research and that "there does not exist any initiative on mathematics education and gender" (p. 88). 
The question “Are multiple choice items biased against girls?” was investigated in relation to the Norwegian data from TIMSS by Grønmo (1998) and her answer was negative. In Denmark, however, the situation was different in 1995. In the report "Myth or reality”, Hoff (1999) analyzed what TIMSS can teach us about gender differences in the Danish mathematics education and she compared these with the Norwegian results. In her more detailed analysis, she showed that the large gender difference in the boys' favour was not general for all items - that some specific areas in mathematics favoured Danish boys while other areas favoured Danish girls. Moreover Hoff showed that the high difference between Danish and Norwegian gender differences was not general for all items, but was concentrated in specific mathematics areas. Her analysis showed that the fraction of Danish 13 year old children who gave blank responses was generally higher than the corresponding fraction of Norwegian children. Generally, the Danish girls gave more blank responses than the Danish boys as well as the Norwegian boys and girls and consequently, the high gender differences decreased if blank responses were subtracted from the incorrect responses. The Norwegian gender differences were on the contrary not altered when blank responses were subtracted from the incorrect responses.

There is a tendency among politicians to accept the survey results. However, the Danish and Norwegian researchers state that the gender issue has to be carefully investigated - also with the use of qualitative methods - before drawing any simplistic conclusions.

\section{Future directions?}

For my presentation of Danish and Norwegian research in mathematics education in this article, I have chosen the approach of "doing gender" with structural, symbolic, personal and interactional perspectives. The focus of this framework is how teachers, boys and girls, men and women, negotiate gender in the world and in their heads. The idea of "doing gender" has been used also to include "being gendered" and "interpreting gender". With this choice of approach, I also wanted to indicate that all major problems are strongly interdependent in mathematics education: "As a matter of fact major problems of education are characterised by the fact that none can properly be isolated from the others. The best you can do at a given moment is to focus on one of them without disregarding the others" (Freudenthal, 1981). Comprehensiveness in research is one way to avoid inappropriate reductions of complexity in the problem field and to ensure that no parts of the subject area are considered in isolation.

In late 1990s, the European commission adopted the principle of gender mainstreaming (the integration of the gender perspective into every step of policy processes - design, implementation, monitoring and evaluation - with the aim of promoting equality between men and women) but apparently without any discernible consequences for mathematics education (see Henningsen, 2004). As we have seen, the problem of doing gender in mathematics has only had a central place in a few studies in Denmark and Norway. However, by including sex as a background variable in their empirical investigations, a series of researchers have been able to draw some lessons on the gender perspective at Nordic conferences. In doing this when the opportunity is given, they demonstrate that they find the issue worthy of their time. Some have explicitly expressed their intentions of focussing on the gender issue - like the group of researchers connected with the Norwegian Center for Mathematics Education in a recent publication (Gjøvik et al., 2005). As a matter of fact, Paul Ernest from the UK held a doctoral course in Trondheim, 2006, with the title "Mathematics and Gender" - the first course of this kind in the Nordic countries. Some of the themes at the course were "public images of mathematics", "mathematics and values", "gender differences in achievement and participation rates" and "theorising the social construction of differences" (Ernest, 
2006). The students were required to choose a topic for investigation from the course related to their doctoral study and to elaborate on this in an essay. One of lessons learned from this course was that it is not possible to extract substantial findings on this issue when one's research project is not designed to study gender perspectives.

Researchers' intentions and a doctoral course - both are sign of possible future directions. In fact, at the Centre for Women and Gender Research (KVINNFORSK), University in Tromsø, Norway, Anne Fyhn is doing a doctoral study with a gender perspective in mathematics education. The starting point of her study is the masters thesis where she tried to answer the question "Does girls' and boys’ physical activity level connect to their understanding of space?” (Fyhn, 2002).

The world of mathematics education does change and so do the structural, symbolic, personal and interactional perspectives on gender. When girls and women are progressing quickly through the educational system, and reforms in mathematics education are more closely allied to feminine values, boys and men will have to find new ways of doing gender in mathematics. We have at least two genders but also many different constructions of gender, dependent on class, ethnicity and culture. The principle of mainstreaming is an argument for setting to work with an explicit gender perspective (structural, symbolic, personal and interactional) in the practice of and research on mathematics education and doing this with due respect for diversity.

\section{Acknowledgements}

Many thanks to Kari Hag, Lisbeth Lindberg and Lena Lindenskov for invaluable help with providing Danish and Norwegian material on the gender and mathematics issue, and to Inge Henningsen, Gail FitzSimons, Jeff Evans, the reviewer and the editor for constructive and critical comments to an earlier version of this article.

\section{References}

Andersen, K. (1991). Kvinder og matematik i vestlige kulturer: fra den græske antik intil omkring 1900. In K. Tingleff (Ed.) (1991). Kvinder og matematik (pp. 23-29).

Berge, L., \& Haga, M. V. (1994). Norway. In L. Burton (Ed.), Who counts? Assessing mathematics in Europe (pp. 171-198). Burton. Stoke-on-Trent: Trentham.

Bjerrum Nielsen, H. (2003). One of the boys? doing gender in Scouting. Génève: World Organization of the Scout Movement.

Bjerrum Nielsen H. and Rudberg, M. (1994). Psychological gender and modernity. Oslo: Universitetsforlaget.

Branner, B.; Faistrup, L.; Kock, H. (1996). Gender and mathematics education in Denmark. In G. Hanna (Ed.), Towards Gender Equality in Mathematics Education: An ICMI Study, Dordrecht: Kluwer Academic Publishers.

Brekke, G., \& Streitlien, Å. (2000). Prosjektet KIM: kvalitet i matematikundervisningen. In K. Hag et al. (Eds.), Handling bak ordene (p. 43-49).

Burton, L. (1990). Gender and mathematics an international perspective. London: Cassell.

Burton, L. (1992). Women and mathematics. In Grevholm, B. (Ed.) (1992). Kvinnor och matematik.

(Conference report, Malmö, 1990) (pp. 10-13). Malmö: Lärarhögskolan i Malmö, Rapporter om utbildning, 1/1992.

Cestari, M. L. (2000). Boys and girls solving mathematical tasks: the co-production of gender dominance. In K. Hag et al. (Eds.) (2000), Handling bak ordene (p. 127-133).

Ernest, P. (2006). Mathematics and gender: doctoral course handbook. Exeter: University of Exeter, School of Education.

EVA (2005). Køn, karakterer og karriere. Drenges og pigers prcestationer i uddannelse. Copenhagen: The Danish Evaluation Institute. 
Fischer, R. (1993). Mathematics as a Means and as a System. In S. Restivo; J. P. van Bendegem; Fischer, R. (Eds.), Math Worlds. Philosophycal and Social Studies of Mathematics and Mathematics Education (pp. 113-133). Albany: State University of N.Y. Press.

Forgasz, H. J., \& Leder, G. C. (1999). The Fennema-Sherman Mathematics as a Male Domain Scale Reexamined. In Journal for Research in Mathematics Education 30(3), 342-347.

Freudenthal, H. (1981). Major problems of mathematical education. Educational Studies in Mathematics, 12, 133-150.

Fuglestad, A. B. (2006). IKT verktøy i matematikk: Gutters og jenters valg og holdninger (ICT tools in mathematics: choice and attitudes of boys and girls). In T. Wedege (ed.) (2006), Kjønn, matematikk og teknikk: Hva skjer når de bringes sammen? (pp. 181-190).

Fyhn, A. (2002). Har jenters og gutters fysiske aktivitetsnivå sammenheng med deres romforståelse? Kvinneforskning, 1/02.

Gjøvik, Ø., Hansen, T. H., Stedøy, I. M., Wedege, T., \& Wæge, K. (2005). Kjønnsperspektiv og matematikk. Tangenten, 16, 69-74.

Grevholm, B. (1992). Kvinnor och matematik. (Conference report, Malmö, 1990). Malmö: Lärarhögskolan i Malmö, Rapporter om utbildning, 1/1992.

Grevholm, B., \& Hanna, G. (Eds.) (1995), Gender and Mathematics Education - an ICMI Study in Stiftsgåarden Åkersberg, Höör, Sweden 1993 (21-38). Lund: Lund University Press.

Grevholm, B., \& Evans, J. (1998). Gender and mathematics. Working group 6 in ICME8. In Proceedings of the $8^{\text {th }}$ international Congress on Mathematical Education (ICME 8 in Seville 1996), (pp. 123-129). Sevilla: SAEM 'Thales'.

Gustafsson, K. (1993). Evnerike jenter og deres skoleprestasjoner i matematikk. In Sekretariat for kvinneforskning, Sånn, ja! (pp.147-155).

Grønmo, L. S. (1995). An overview of TIMSS focusing on gender issues in the study. In B. Grevholm \& G. Hanna (Eds.), Gender and Mathematics Education (pp. 199-206).

Grønmo, L. S. (1998). Are multiple choice items biased against girls? In L. Lindberg \& B. Grevholm (eds.) Kvinnor och matematik (Conference report, Göteborg, 1996) (pp. 93-104). Göteborg: Göteborg Universitet, Institutionen for ämnesdidaktik.

Grønmo, L. S., \& Kjærnsli, M. (2000). Norge: på verdenstoppen i kjønnsforskjeller i matematikk og naturfag? In K. Hag et al. (eds.), Handling bak ordene (pp. 29-39).

Hag, K. (1996). Gender and mathematics education in Norway. In G. Hanna (Ed.), Towards Gender Equality in Mathematics Education: An ICMI Study, Dordrecht: Kluwer Academic Publishers.

Hag, K. (1998). Norges første kvinnelige matematiker. In L. Lindberg \& B. Grevholm (Eds.) Kvinnor och matematik (Conference report, Göteborg, 1996) (pp. 105-112). Göteborg: Göteborg Universitet, Institutionen for ämnesdidaktik.

Hag, K. (2000). Kvinner i matematikken: hvorfor så få? In A. M. Skarsbø (Ed.), Women in science (pp. 1928).

Hag, K.; Holden, I.; Marion P. van (Eds.) (2000). Handling bak ordene: artikler om jenter og matematikk. Trondheim: Norges teknisk-naturvitenskapelige universitet.

Hanna, G. (1993). Retaining women in mathematics and science. In Sekretariat for kvinneforskning, Sånn, ja! (pp. 29-41).

Hanna G. (Ed.) (1996). Towards Gender Equality in Mathematics Education: An ICMI Study, Dordrecht: Kluwer Academic Publishers.

Hansen, K. Grønbæk (1991). Matematik har køn og klasse; men hvad betyder det for de unge i erhvervsuddannelserne. In K. Tingleff (Ed.) (1991). Kvinder og matematik (pp. 50-54).

Hansen, Kirsten Grønbæk (2000). Situeret læring i klasserummet. In K. Illeris (red.), Tekster om løering (pp. 206-224). Roskilde: Roskilde Universitetscenter.

Henningsen, I. (2002). Gender in ALM: Women and men learning mathematics. In L. Ø. Johansen \& T. Wedege (red.), Numeracy for empowerment and democracy? Proceedings of the $8^{\text {th }}$ International Conference on Adults Learning Mathematics (ALM8), 2001 (pp. 223-232). Roskilde: Centre for Research in Learning Mathematics, Roskilde University. 
Henningen, I. (2004). Gender mainstreaming of research on adult mathematics education: opportunities and challenges. Published by Topic Study Group 6, Adult and lifelong Mathematics Education. $10^{\text {th }}$ International Congress on Mathematics Education. Available at www.icme-10.dk

Hoff, A. (1999). Myth or reality: what can TIMSS teach us about gender difference in the Danish science and math education? An introductory survey. Copenhagen: The Royal Danish School of Educational Studies, Dep. of Mathematics, ... Publication no. 36.

Holden, I. (2000). Matematikk i småskolen: leik i fag og fag i leik. In K. Hag et al. (Eds.) (2000), Handling bak ordene (pp. 53-60).

Høyrup, E. (1978). Women and mathematics science and engineering: partially annotated bibliography with emphasis on mathematics and with references on related topics. Roskilde: Roskilde University Library.

Haastrup, K., \& Lindenskov, L. (1994). Denmark. In L. Burton (ed.), Who counts? Assessing mathematics in Europe (pp. 23-40). Burton. Stoke-on-Trent: Trentham.

Kaiser, G. \& Rogers, P. (1995). Introduction: equity in mathematics education. In P. Rogers \& G. Kaiser (Eds.), Equity in mathematics education: influences of feminism and culture (pp. 1-10). London: The Falmer Press.

Kaiser, G. (2003). Feminist Frameworks for Researching Mathematics. In Pateman, N.; Dougherty, B.; Zilliox, J. (Eds.), Proceedings of the 2003 Joint Meeting of PME and PMENA, Vol. 1 (pp. 157-160). Honolulu: University of Hawaii.

Kjeldsen, T. Hoff (ed.) (2001). Kvinder og matematik: netværk og myter. Matilde - Newsletter of the Danish Mathematical Society, no. 9, May 2001.

Leder, G C., Forgasz, H. J. \& Solar, C. (1996). Research and Intervention Programs in Mathematics Education: A Gendered Issue. Chapter 25 in A.J. Bishop et al. (eds.), International Handbook of Mathematics Education (945-985).Dordrecht: Kluwer Academic Publishers.

Leder, G. C. (2000). Once upon a time to the present: mathematics education and gender - past, present, and future. In K. Hag et al. (Eds.) (2000), Handling bak ordene (p. 7-28).

Leder, G. C., \& Brandell, G. (2004). Mathematics still a male domain? Preliminary data from a Swedish study. In Grevholm, B. and Lindberg, L. (eds.), Kvinnor och Matematik. (Conference report, 2002, Kristiandstad) (pp. 63-69). Lund: Högskolan i Kristiansand.

Lindenskov, L. (1991) En hyldest til nysgerrigheden - med eksempler fra en undersøgelse om hverdagsvidens indflydelse på indlæringsproblemer i matematik i gymnasiet. In Tingleff, K. (Ed.), Kvinder og matematik (pp. 15-21).

Lindenskov, L. (2000). Fascination, selvfremstilling og køn i skolens matematikundervisning. In K. Hag et al. (Eds.) (2000), Handling bak ordene (pp. 109-123).

Lindenskov, L., \& Weng, P. (2004). Matematisk kompetence. In J. Meiding (ed.), PISA 2003: Danske unge i en international sammenligning (pp. 35-96). Copenhagen: Danmarks Pædagogiske Universitets Forlag.

Mellin-Olsen, S. (1995). Mathematics education: women’s talk. Landås, Norway: Caspar Forlag.

Piene, R. (1994). Kvinnlige matematikere i Norden og i Europa: i dag og i morgen. In G. Brandell \& B. Grevholm (Eds.), Kvinnor och matematik, Konferensrapport Luleå 1993. Luleå: Institutionen för matematik, Högskolan i Luleå.

Sekretariat for kvinneforskning (1993). Sånn, ja! Rapport fra en konferanse om matematikk-didaktikk og kvinner i matematiske fag. Kristiansand 8.-10. maj 1992. Oslo: Norges forskningsråd, Arbejdsnotat 2/93.

Skarsbø, A. M. (Ed.) (2004). Women in science: a conference report. Bergen: University of Bergen, Centre for Women's and Gender Research.

Skaalvik, E. M. (1990). Gender differences in general academic self-esteem and in success expectations on defined academic problems. Journal of Educational Psychology, 82(3), 593-598.

Strässer, R. (2006). Gender and Information Technology: a complicated issue. In T. Wedege (Ed.) (2006), Kjønn, matematikk og teknikk (pp. 197-199).

Tingleff, K. (Ed.) (1991). Kvinder og matematik. rapport fra konference på N. Zahles Gymnasieskole d. 21.22. september 1991. Nordby, Samsø: Planlægningsgruppen, ”Matematik”.

Vedelsby, M. (1998). Informationsteknologi og matematik i den danske folkeskole. In L. Lindberg \& B. Grevholm (Eds.) Kvinnor och matematik, Konferensrapport Göteborg 1996 (pp. 189-196). Göteborg: Göteborg Universitet, Institutionen for ämnesdidaktik.

Vedelsby, M. (2000). Integration af ny teknologi i skolens matematikundervisning: kan det gøres 
meningsfyldt for både piger og drenge? In K. Hag et al. (Eds.), Handling bak ordene (pp. 95-108).

Walkerdine, V. (1991). Girls, women and mathematics. In K. Tingleff (ed.), Kvinder og matematik. rapport fra konference på N. Zahles Gymnasieskole d. 21.-22. september 1991 (pp. 50-54). Nordby, Samsø:

Planlægningsgruppen, "Matematik”.

Wedege, T. (2002). Mathematics in a woman's school and everyday life. In B. Grevholm; I. Sigstam, A. Vretblad. Kvinnor och matematik. (Conference report, Uppsala, 1999) (pp. 179-188). Uppsala: Uppsala universitet, Matematiska institutionen.

Wedege, T. (Ed.) (2006). Kjønn, matematikk og teknikk: Hva skjer når de bringes sammen? (Gender, mathematics and technology: what happens when they are brought together?). In IKT $i$

matematikkundervisningen: muligheder og begrensninger, Konferanserapport, no. 4, 2006. Trondheim: Nasjonalt senter for matematikk i opplæringen.

Wedege, T., \& Skott, J. (2006). Changing views and practices? A study of the KappAbel mathematics competition. Research report. Trondheim. Norwegian Center of Mathematics Education.

West, C. \& Zimmerman, D. H. (1987). Doing Gender. Gender \& Society, 1(2), 125-151.

Weng, P. (1996). Matematik og naturvidenskab i folkeskolen: en international undersøgelse. (TIMSS 1995). Copenhagen: Danmarks Pædagogiske Institut.

\section{Author}

Tine Wedege

The School of Teacher Education

Malmö University,

20605 Malmö

Sweden

Email: tine.wedege@mah.se

The Department of Mathematical Sciences

Norwegian University of Technology and Science

Trondheim

Norway 